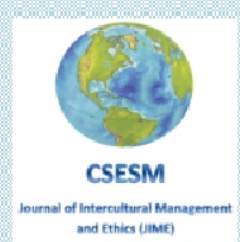

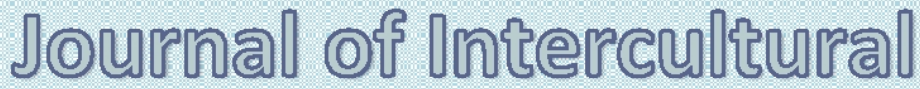

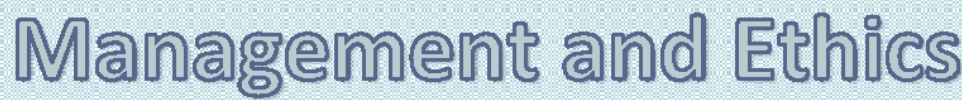

\author{
IOME
}

ISSN 2601 - 5749, ISSN-L 2601 - 5749

\section{published by zy \\ Center for Socio-Economic Studies and Multiculturalism \\ lasi, Romania \\ Waw csesmorg}




\section{Special Editor}

\section{Professor Beatrice Gabriela Ioan, PhD, MD}

Grigore T.Popa University of Medicine and Pharmacy of Iasi, Romania

E-mail: ioanbml@yahoo.com

\section{TABLE OF CONTENT}

Editorial

Beatrice Gabriela Ioan

Global Pandemics: Considerations of Public Health, Human Rights, and Bioethics

SanaLoue

Reactions of Bioethics to the Covid-19 Pandemic 19

Elena Toader, Luiza Palamaru, Tudor Stefan Rotaru, Oana Hrisca Eva

Implications of Cognitive-Behavioural Therapy in Changing Illness Representations .27

Ancuța Elena Păduraru, Camelia Soponaru

Healthcare Workers - Heroes and Villains in Covid-19 Pandemic. The Ethical

Communication

Ioana Silistraru

Ethical Dilemmas in the Therapeutic Management of Patients with Sars-Cov-2 Infection .. 45 Claudia Elena Pleşca, Ioana Hunea, Maria Obreja, Oana Stămăteanu, Delia Luchian, Irina Dima, Larisa Miftode, Tudorița Gabriela Părângă, Egidia Miftode, Simona Apostu, Camelia Bucur, Daniela Leca

Covid - 19 through the Window of Age 55

Elena Toader, Daniela Damir, Tudor Winzinger

Ethical Aspects of "Do Not Resuscitate" Orders in the Context of the Covid-19 Pandemic 61 Iulius Connor Gramma, Gema Bacoanu, Beatrice Gabriela Ioan

Ethics of the Human-Animal Relationship in the Covid-19 Pandemic .67

Cristin Coman, Diana Ancuta 


\title{
GLOBAL PANDEMICS: CONSIDERATIONS OF PUBLIC HEALTH, HUMAN RIGHTS, AND BIOETHICS
}

\author{
Sana Loue \\ Case Western Reserve University School of Medicine \\ Cleveland, Ohio, USA \\ e-mail: Sana.Loue@ case.edu
}

\begin{abstract}
Pandemics threaten the health and lives of peoples worldwide, sometimes requiring the imposition of numerous, restrictive public health measures to diminish their impact and preserve health and life. Such measures, however well-intended, have the potential to contravene human rights and raise significant ethical questions at the individual, community, national, and international levels. This article explores the impact of public health measures adopted in an effort to ameliorate the transmission of COVID-19 on access to care, the right to privacy, protection of marginalized communities from discrimination, and violence against women. The discussion of bioethical concerns focuses on resource allocation, the presumed obligation of healthcare workers to provide care, and governmental obligations in the face of a pandemic. The discussion concludes with a review of lessons learned: the need for a coordinated response across levels of government and the private sector, attention to existing structural inequalities that may exacerbate the impact of the pandemic and/or the public health measures adopted to contain the pandemic, the protection of vulnerable and marginalized persons, a clear delineation of and support for workers deemed to be essential, and the provision of relevant training to law enforcement personnel.
\end{abstract}

Key words: bioethics, human rights, pandemic, privacy, public health, vulnerability

\section{Introduction}

The word "pandemic" derives from Greek: pan, meaning all and demos, referring to people. Pandemics occur on a large scale, involve an infectious/contagious disease, and sustained community transmission. It has been suggested that the frequency of pandemics has increased during the past century as the result of more widespread travel, urbanization, and environmental change. Many of the recent pandemics, including HIV/AIDS, SARS, and COVID-19 are viral diseases that originated in wildlife (Morse et al., 2012).

There have been numerous pandemics throughout recorded history, with varying impacts globally. Two widely known pandemics that have been the subject of both scientific literature and popular literature include the Black Death and the Spanish flu. The Black Death, also known as "The Great Dying," (1346-1353), caused by Yersinia pestis, led to the deaths of more than one-third of Europe's population (Cohn, 2002; Langer, 1964). It is believed that an H1N1 virus of avian origin was responsible for the 1918 "Spanish flu" epidemic, which caused approximately 500 million people to become infected, representing one-third of the world's population, and 50 million to die (Patterson and Pyle, 1991). Table 1 below provides a listing of various pandemics that have occurred since the mid-fourteenth century, their causes, and their impact. 
Table 1. Selected Pandemics From the Fourteenth Century Onwards, Their Causes, and Impacts

\begin{tabular}{|c|c|c|c|c|c|c|c|}
\hline 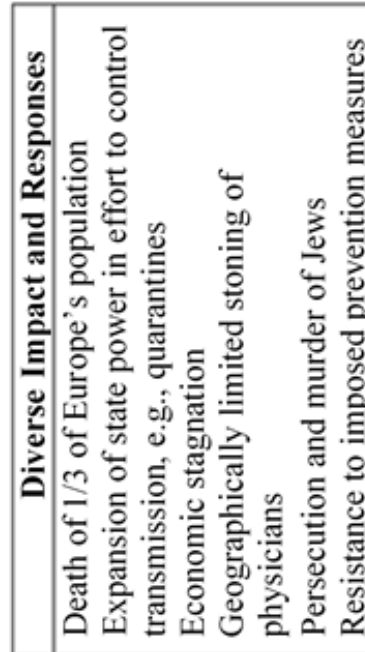 & 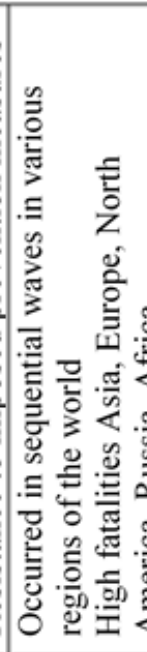 & 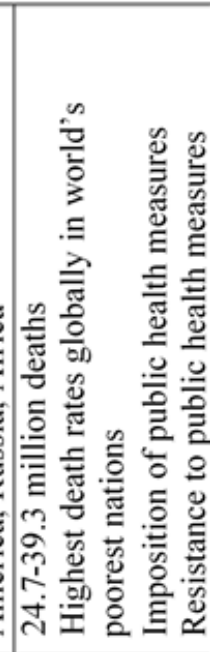 & 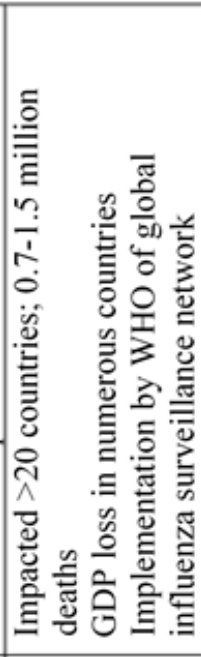 & 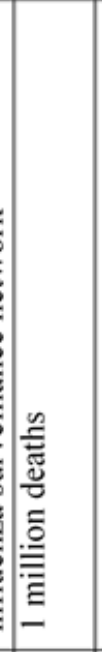 & 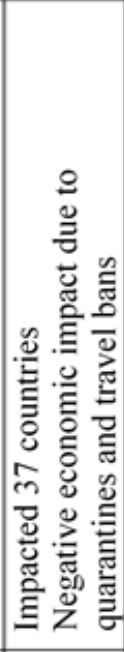 & 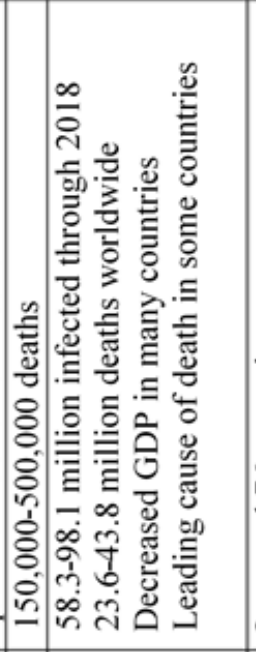 & 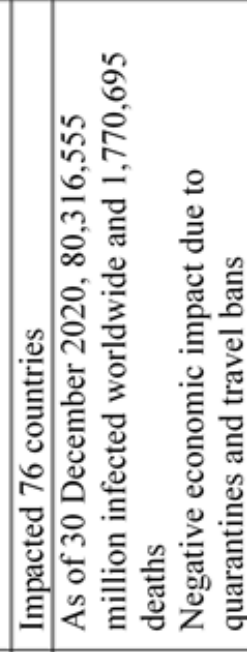 \\
\hline 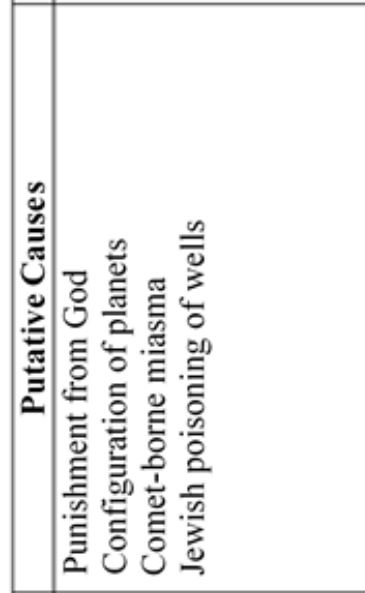 & 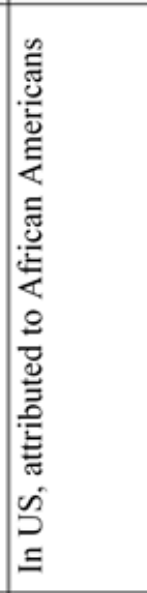 & 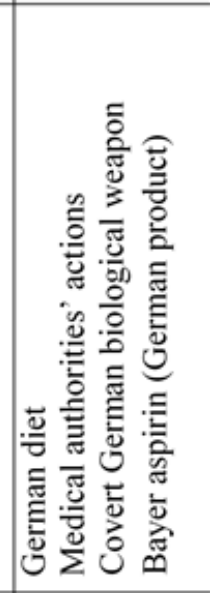 & 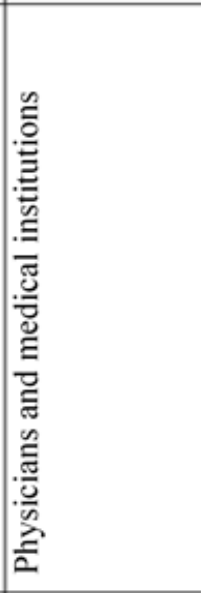 & & & 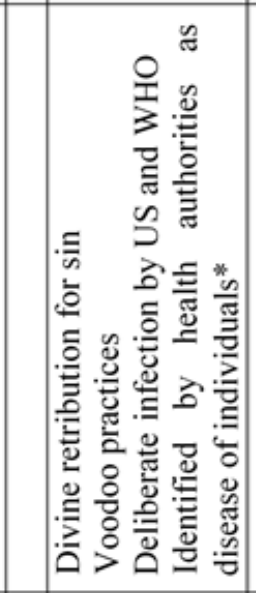 & \\
\hline 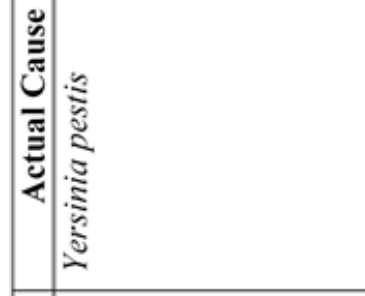 & 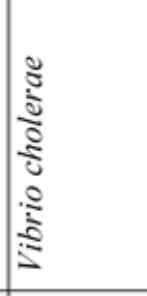 & $\bar{Z}$ & ב̃ & 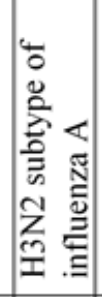 & & $\bar{z}$ & \\
\hline 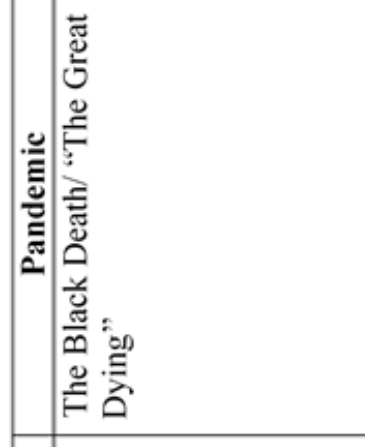 & $\frac{\frac{\pi}{2}}{\frac{2}{0}}$ & 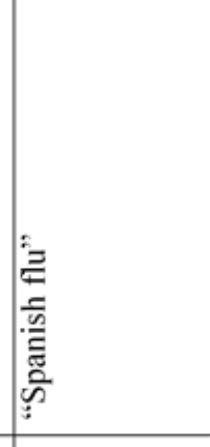 & 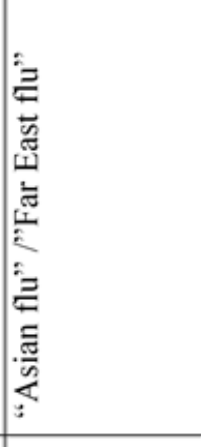 & 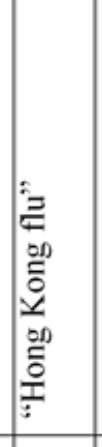 & 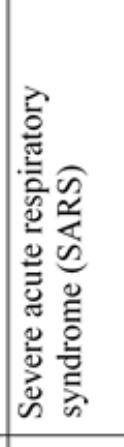 & 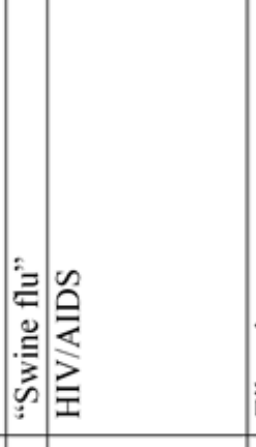 & 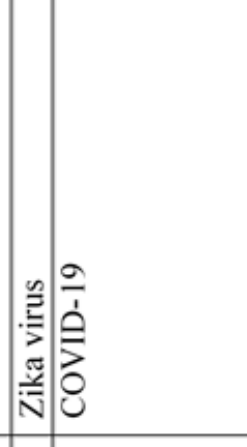 \\
\hline 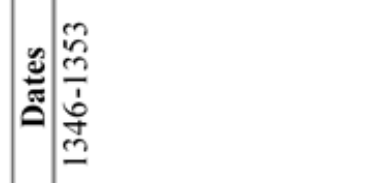 & 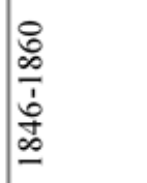 & $\frac{\frac{\partial}{a}}{\frac{\partial}{\alpha}}$ & 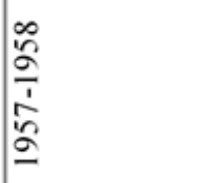 & 离 & ֻัे & 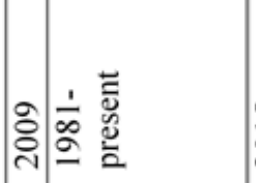 & 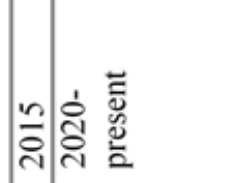 \\
\hline
\end{tabular}


Sources: Blakely, 2003; Cohn, 2002; Desmond, Lieberman, Alban, and Ekström, 2008; European Centre for Disease Control and Prevention, 2020; Galishoff, 1969; Henderson, Courtney, Inglesby, Toner, and Nuzzo, 2009; Langer, 1964; Morse et al., 2012; Paluzzi and Farmer, 2004; Patterson and Pyle, 1991; Pollitzer, 1959; Slack, 1988; Tognotti, 2013

*AIDS was initially attributed to members of four subgroups: Haitians, hemophiliacs, homosexual, and heroin addicts. This became known as the "4-H theory" or "4-H club" (Paluzzi and Farmer, 2002).

\section{Strategies for Pandemic Management}

Public health measures for pandemic management focus on containment, mitigation, and suppression. The implementation of these strategies varies depending upon a variety of factors.

Containment is utilized during the early stages of a pandemic to minimize the risk that infected persons will transmit the infection to noninfected individuals. Measures include contact tracing and the isolation of individuals who are known to be infected.

Mitigation strategies are those that are used to slow the spread of the disease and reduce the peak of demand on health care services, i.e., "flattening the curve." Depending upon the cause of the pandemic, mitigation strategies may include personal preventive measures such hand washing and the use of protective materials, for example, condoms in the case of HIV/AIDS and face masks in the case of respiratory transmission. Physical distancing between individuals may also be utilized; this may be done voluntarily or, in some cases, authorities may impose limited curfews or mandate staggered or limited work hours in an effort to limit physical contact between persons (Aimone, 2010). Environmental measures may also be helpful, such as the physical distancing of seating and the reconfiguration of air flow. During the 1918 influenza epidemic, New York City enacted measures that required individuals to protect their nose and mouth while sneezing and coughing and to cease spitting in public (Aimone, 2010). Immunization constitutes a critical mitigation strategy when it is available (Henderson, Courtney, Inglesby, Toner, \& Nuzzo, 2009). Research suggests that the use of containment and mitigation measures together may be most effective for slowing the spread of disease (Organisation for Economic Co-operation and Development, 2019).

Suppressive measures are necessary in situations in which the infectious contagion has led to widespread infection. Measures may include population-wide physical distancing, such as travel bans, the isolation of cases, and large-scale quarantine of a population. The 1918 flu pandemic illustrates how population movement may facilitate or exacerbate viral transmission. The flu pandemic occurred during wartime; transmission was facilitated by troop movement, wartime disruption, and improved railroad networks (Patterson \& Pyle, 1991)

Although these public health measures may be important to slow or halt the transmission of an infectious agent, their imposition may lead to tensions between individual rights and measures for the collective good. Foremost among these are the rights to freedom of movement, the right to health, and the right to privacy. Additionally, measures that are implemented in an effort to protect the public health may inadvertently increase risks to subgroups within a population.

\section{Human Rights and Public Health}

There appears to be widespread agreement that specified rights may not be derogated (Council of Europe, 1950). These include the right to life, a prohibition against torture and ill treatment, the prohibition against slavery, and the requirement that punishment be premised on law (Lebret, 2020). Other rights may be curtailed only under specified circumstances. Article 4(1) of the International Covenant on Civil and Political Rights provides for the derogation of derogable rights in the "time of public emergency which threatens the life of 
the nation." The American Convention on Human Rights suggests in Article 27(1) that some rights may be curtailed in "time of war, public danger, or other emergency that threatens the independence or security of a State Part." The European Convention for the Protection of Human Rights and Fundamental Freedoms in Article 15 permits the implementation of measures that are "strictly required by exigencies of the situation," if they are not inconsistent with other international law obligations and do not discriminate between nationals and nonnationals (Council of Europe, 1950).

Accordingly, some rights may be limited in the face of emergency situations. Even then, however, deprivations of liberty must be reasonable, necessary and proportionate (UNAIDS, 2020). Any limitations are to be specific, time-bound, and evidence-based, with adjustments made in response to new information. The promulgation of criminal laws as a mechanism to enforce public health measures presents the risk of discriminatory enforcement against members of stigmatized or marginalized groups. (UNAIDS, 2020. See Chamas, 2020 for an example of where this has occurred.)

The World Health Organization in 1946 recognized "the highest attainable standard of health as a fundamental right of every human being." The Committee on Economic, Social and Cultural Rights (2000) recognized that [h]ealth is a fundamental human right indispensable for the exercise of other human rights. Every human being is entitled to the enjoyment of the highest attainable standard of health conducive to living a life in dignity.

Numerous international documents have indicated that states have an obligation to ensure access to timely, acceptable, affordable health care of appropriate quality, and/or to address the underlying determinants of health (Committee on Economic, Social and Cultural Rights, 2000). These include, as examples, the Universal Declaration of Human Rights (1948), the European Social Charter (1961), the Convention on the Rights of Persons with Disabilities (2007), the American Declaration on the Rights and Duties of Man (1948), the Convention on the Rights of the Child (1989), and the International Covenant on Economic, Social and Cultural Rights (1966). This right is central to, and necessarily dependent on, the realization of other human rights, including the right to food, housing, work, education, information, and participation (International Covenant on Economic, Social and Cultural Rights) and, as indicated in the International Convention on the Elimination of Racial Discrimination (1965), is to be enjoyed without discrimination due to race, age, ethnicity, or any other status.

Although measures such as quarantines and lockdowns may be imposed as part of a strategy to reduce disease transmission and protect public health, they may also lead to the deterioration of patients' health and an exacerbation of their existing difficulties accessing care (UNAIDS, 2020). Patient health may be threatened and their access to health care may be curtailed because the imposed lockdowns and quarantine measures require that they remain at home, even when needing emergency care (Biryabarema, 2020; Landman \& Okereke, 2020). Health care workers may be unable to travel to their places of employment as a result of these measures, placing additional strain on already overburdened and overwhelmed health care systems (UNAIDS, 2020).

The right to privacy is reflected in the International Covenant on Civil and Political Rights (1966), which recognizes the obligation to protect individuals from unlawful, arbitrary interference with privacy, home, family, and correspondence. The use of drones, cell phone tracing, and contact tracing to detect infected individuals and warn others of possible contact clearly conflict with this right to privacy (CBSNews, 2020; Halpern, 2020; Kharpal, 2020).

The imposition of public health measures such as isolation, quarantine, and lockdowns may disproportionately impact vulnerable populations and lead to the inadvertent contravention of human rights. Groups most likely to be adversely impacted include the aged, the very young, those with pre-existing medical problems, prisoners, women, and 
socially disadvantaged and marginalized groups (Ontario Human Rights Commission, 2020; UNAIDS, 2020). As one example, researchers have found in their examination of public health measures adopted to control the spread of COVID-19 measures that women in particular have been adversely impacted. The pandemic is expected to push up to 96 million people into poverty during 2021; 47 million of these individuals are women. Women-run businesses have been particularly impacted by the public health measures. Additionally, responsibilities for caregiving and home schooling, made necessary due to governmentimposed quarantines and lockdowns, have fallen disproportionately on women, often impacting their careers. The Convention on the Elimination of All Forms of Discrimination Against Women (1979) prohibits gender-based violence, but violence against women has increased due to the pandemic with its associated lockdowns and quarantines, leaving many women isolated from supportive resources (Abramian, 2020), a phenomenon that has been called the shadow pandemic (United Nations Women, n.d.). As an example, cases of partner violence against women have increased by 50 to 60 percent in the Eastern Mediterranean region and 30 percent in France (United Nations Department of Global Communications, 2020; World Health Organization Regional Office for the Eastern Mediterranean, 2020).

Roma individuals have been adversely impacted not only by the COVID-19 pandemic, but by the public health measures that have been implemented in an effort to control transmission (European Commission, 2020; European Union Agency for Fundamental Rights, 2020). Approximately 30 percent of Roma individuals live in housing that lacks tap water, and 40 percent lack sanitary facilities inside their dwellings. In some areas, up to 80 percent of the Roma population lives in cramped overcrowded neighborhoods, and many must migrate to work. The imposition of quarantines leads to individuals' confinement in already cramped spaces, and travel bans lead to individuals' inability to earn wages sufficient to provide adequate food and water. Because much of their work is in the informal sector, they may be unable to access unemployment benefits (European Commission, 2020; European Union Agency for Fundamental Rights, 2020).

In the United States, public health measures implemented in an effort to slow or halt the transmission of COVID-19 have had a disproportionate impact both on members of minority groups and on women (van Dorn, Cooney, \& Sabin, 2020). Many minorities live in higher-density spaces, making it difficult to physically distance in response to quarantine measures (Wilder, 2020). Some minority individuals may be unable to quarantine because they work in essential occupations (Gordon, 2020; Wilder, 2020). Business closures in response to public health concerns have led to the furlough or termination of workers who were not deemed to be essential, leaving many women in lower-paying jobs furloughed or terminated (Bateman \& Ross, 2020). Women have had to assume a disproportionate share of the consequences of school and day care closures, e.g., home schooling and heightened child care demands.

\section{Bioethical Issues in Pandemic Management}

Pandemic management raises numerous bioethical issues in both the clinical and research contexts at the individual, community, national, and global levels. Table 2 below provides a listing of many of the issues at each level. It is beyond the scope of this manuscript to examine each of these various issues in detail. Accordingly, this discussion focuses specifically on the issues of resource allocation at the individual, community, national and global levels; the asserted obligation of health care workers to provide care; and the obligations of government vis-à-vis those within its borders. 
Table 2. Listing of Bioethical Issues Arising in Pandemic Situations

\begin{tabular}{|l|l|l|l|l|}
\hline & \multicolumn{1}{|c|}{ Individual } & \multicolumn{1}{c|}{ Local Community } & \multicolumn{1}{c|}{ Nation } & \multicolumn{1}{c|}{ Global } \\
\hline $\begin{array}{l}\text { Clinical } \\
\text { context }\end{array}$ & $\begin{array}{l}\text { Autonomy } \\
\text { Resource allocation } \\
\text { Availability of and } \\
\text { access to non-validated } \\
\text { treatments } \\
\text { Health care worker } \\
\text { obligation to treat }\end{array}$ & $\begin{array}{l}\text { Fair resource } \\
\text { allocation/ sharing } \\
\text { Availability of and } \\
\text { access to non- } \\
\text { validated treatments }\end{array}$ & $\begin{array}{l}\text { Fair resource } \\
\text { allocation/ sharing } \\
\text { Availability of and } \\
\text { access to non-validated } \\
\text { treatments }\end{array}$ & $\begin{array}{l}\text { Fair resource } \\
\text { allocation/ sharing }\end{array}$ \\
\hline $\begin{array}{l}\text { Research } \\
\text { context }\end{array}$ & $\begin{array}{l}\text { Protection of individual } \\
\text { vs. individual autonomy } \\
\text { Protection of } \\
\text { participants and } \\
\text { communities in context } \\
\text { of need for expedited } \\
\text { review }\end{array}$ & $\begin{array}{l}\text { Research } \\
\text { collaboration as } \\
\text { means of maximizing } \\
\text { resources } \\
\text { Data sharing } \\
\text { Community } \\
\text { engagement }\end{array}$ & $\begin{array}{l}\text { Acceptability of } \\
\text { challenge studies and } \\
\text { deferred consent } \\
\text { Data sharing } \\
\text { Balancing of resources } \\
\text { needed for pandemic } \\
\text { control and research }\end{array}$ & $\begin{array}{l}\text { Data sharing } \\
\text { Balancing of } \\
\text { resources needed } \\
\text { for pandemic } \\
\text { control and research } \\
\text { Obligation to } \\
\text { support other } \\
\text { nations }\end{array}$ \\
\hline
\end{tabular}

Sources: Smith and Upshur, 2019; World Health Organization, 2020 (May 6)Resource Allocation

As indicated in Table 2, issues of resource allocation arise at the individual, organization, national, and global levels. As an example, in the context of the COVID-19 pandemic, we find that there are a limited number of beds, intensive care beds, ventilators, and certain potentially beneficial treatments to be had. Health care providers frequently confront a situation in which they must decide which of their patients are to receive these potentially lifesaving resources. Resource allocation is also impacted by service priorities at an organizational or institutional level; is the hospitalization and treatment of COVID-19infected patients to take precedence over that needed by patients with non-COVID-19-related health concerns? Given that the availability of ventilators, specific treatments, and trained health care workers is limited, how is a nation to allocate these resources to the many areas of need? And, in view of the vast disparities between countries of wealth and those with fewer resources, how are the available resources to be made available and distributed globally? How such questions are answered may not only enlarge or reduce currently existing health disparities between individuals, communities, populations, and nations, but also challenge the precept of "the highest attainable standard of health" as a human right (van Dorn, Cooney, \& Sabin, 2020; Olivarius, 2020).

Numerous frameworks have been devised as ethical guides to a pandemic response (Daniels, 1994; Persad, Wertheimer, \& Emanuel, 2009). The University of Toronto Joint Centre for Bioethics Pandemic Influenza Working Group (2005) has suggested that an ethical response requires consideration of both substantive and procedural values. Substantive values include individual liberty, protection of the public from harm, proportionality, privacy, a duty to provide care, reciprocity, equity, trust, solidarity, and stewardship. Procedural values encompass reasonableness, transparency, inclusivity, responsiveness, and accountability.

Adoption of such a framework would require that a schema for the allocation of resources reflect consideration of each enumerated value. A variety of approaches to resource allocation have been proposed:

- allocation to save the most lives (Manelli, 2020)

- prioritization of the sickest individuals (Christian et al., 2020)

- allocation to those with shorter lives (Christian et al., 2020; New York State Task Force on Life and the Law, New York State Department of Public Health, 2015)

- allocation to maximize the total number of life years or quality-adjusted life years (see Melnychuk \& Kenny, 2006) 
- distribution first to the most vulnerable

- priority to those who are instrumental to the pandemic response (New York State Task Force on Life and the Law, New York State Department of Public Health, 2015)

- allocation based on a lottery system (Brock, 1988).

A specific resolution to questions of resource allocation may necessarily vary depending upon a constellation of factors including, but not limited to, the clinical characteristics of the population requiring the care and the level of scarcity, and understandings derived from community engagement,

\section{The Obligation to Provide Care}

It is often assumed that health care workers, and physicians in particular, have a duty to provide care in the context of a pandemic (see, e.g., New York State Task Force on Life and the Law, New York State Department of Health, 2015). This assertion derives from several arguments: that they expressly agreed to provide care as a necessary condition of their employment; that having entered into medicine, they gave their implied consent to provide care and society has a legitimate moral expectation that they do so (Fleck, 2003); that, having received specialized training, health care workers have an obligation to provide care; that providers have a reciprocal duty to provide care having received benefits and/or privileges associated with their education and/or employment; and that physicians have taken an oath and are bound by a professional code of ethics that requires that they provide care (Clark, 2005). Others, however, have argued that any of these grounds is inadequate to support the proposition that a healthcare worker has a duty to treat in the context of a pandemic (Malm, May, Francis, Omer, Salmon, \& Hood, 2008). Indeed, although many physicians have provided care even at great risk to themselves (Shanks, MacKenzie, Waller, \& Brundage, 2011; Walker \& Whitty, 2015), history also presents us with numerous examples in which physicians chose to refuse or withhold care for fear that they or their family members might become infected (Jauhar, 2020; Zuger \& Miles, 1987).

At least one author has suggested that, if such a duty exists, it is not unconditional but is rather reciprocal (Jauhar, 2020). Reciprocity would suggest that members of the public have a concomitant obligation to act responsibly, in conformity with public health recommendations designed to reduce the risk of transmission; that health care institutions and governmental entities have an obligation to ensure an adequate infrastructure through, for example, the provision of necessary personal protective equipment to reduce providers' risk of infection; and that providers, should they become ill, are provided with adequate treatment. In the context of the COVID-19 pandemic, the dedication demonstrated by health care workers, at times even at the expense of their own health and lives, has not been evenly reciprocated by members of the public, governmental personnel and entities, and healthcare institutions. Members of the public, even governmental officials, have refused to adhere to public health recommendations to reduce transmission; personal protective equipment has been scarce and sometimes completely unavailable (Finkenstadt, Handfield, \& Guinto, 2020; Glenza, 2020; World Health Organization, 2020, March 3); health care institutions and governments have sanctioned health care workers for making their needs known publicly (Scheiber \& Rosenthal, 2020); and governments have failed to develop the networks and infrastructure critical to efforts to control the pandemic and protect health care providers and the general populace (Amnesty International, 2020; Carville, Court, \& Brown, 2020; Finkenstadt, Handfield, \& Guinto, 2020).

\section{Government Responsibilities}

Various frameworks have been proposed in an effort to assist governments with the formulation of an ethical response to pandemics. One proposal suggests that the principle of 
equal concern and respect, comprising the minimization of harm, fairness, collaborative action, proportionality, flexibility, reciprocity, and good decisionmaking, should guide all decisionmaking (Gad, 2020). Adoption of this framework would seem to require transparency and openness, community engagement, a willingness to modify course as new information becomes available, coordination and collaboration between levels of government and the private sector, and the provision of support to both those who are asked to bear a disproportionate share of the responsibility during the pandemic and those who are especially vulnerable. As an example, government support likely would, under this framework, include the provision of housing for homeless persons, both to protect that subset of the population and to protect the population as a whole (Holmes, 2020). Others have framed the principle of collaborative action in terms of solidarity, said to encompass the sharing of data and the deployment of human and material resources (Ireland Department of Health, 2020).

Additional values have been identified as critical to the formulation of ethical decisionmaking during a pandemic. These include inclusiveness of stakeholders to the greatest extent possible, accountability of decisionmakers at all levels, and appropriate systems to foster accountability (French, 2011; Ireland Department of Health, 2020; Singer et al., 2003).

\section{Lessons Learned}

The historical experience of pandemics suggests that several elements are critical components of an effective public health response that is both ethical and consistent with human rights. These include: a coordinated response across levels of government and the private sector, attention to existing structural inequalities that may exacerbate the impact of the pandemic and/or the public health measures adopted to contain the pandemic, the protection of vulnerable and marginalized persons, and a clear delineation of and support for workers deemed to be essential. The various excesses that may occur through the enforcement of public health measures such as quarantine and isolation and that lead to individuals' inability to access care and increased stress on the health care system may be reduced by providing relevant training to law enforcement personnel.

Acknowledgements: Portions of this article were presented as a keynote address at the National Conference on Bioethics on Ethical Challenges in the Context of the VOVID-19 Pandemic, December 10-12, 2020 (Romania). This work was supported in part by the Fogarty International Center, R25 TW01507.

\section{References}

Abramian, J. (2020). The Covid-19 pandemic has escalated domestic violence worldwide. Forbes, July 22. https://www.forbes.com/sites/jackieabramian/2020/07/22/the-covid19-pandemic-has-escalated-global-domestic-violence/?sh=13e79c25173e. Accessed December 9, 2020.

Aimone, F. (2010). The 1918 influenza epidemic in New York City: A review of the public health response. Public Health Reports, 125(Suppl. 3), 71-79.

American Declaration on the Rights and Duties of Man. (1948). Adopted by the Ninth International Conference of American States, Bogota, Colombia, May 2.

Amnesty International. (2020, July 13). Global: Health care workers silenced, exposed and attacked. https://www.amnesty.org/en/latest/news/2020/07/health-workers-rightscovid-report/. Accessed December 31, 2020.

Bateman, N., \& Ross, M. (2020). Why has COVID-19 been especially harmful for working women? Brookings Institution, October. https://www.brookings.edu/essay/why-has- 
covid-19-been-especially-harmful-for-working-women/. Accessed December 31, 2020.

Biryabarema, E. (2020). In Uganda, mothers in labour die amidst coronavirus lockdown. Reuters, April 9. https://www.reuters.com/article/us-health-coronavirus-uganda/inuganda-mothers-in-labour-die-amidst-coronavirus-lockdown-idUSKCN21R2FA. Accessed December 30, 2020.

Blakely, D.E. (2003). Social construction of three influenza pandemics in the New York Times. Journal \& Mass Communication Quarterly, 80(4), 884-902.

Brock, D.W. (1988). Ethical issues in recipient selection for organ transplantation. In D. Mathieu (ed.), Organ substitution technology: Ethical, legal and public policy issues (pp. 86-99). London: Westview Press.

Buckley, C. (2020). Chinese doctor, silences after warning of outbreak, dies from coronavirus. New York Times, February 6.

Carville, O., Court, E., \& Brown, K.V. (2020). Hospitals tell doctors they'll be fired if they speak out about lack of gear. Bloomberg, March 31. https://www.bloomberg.com/news/articles/2020-03-31/hospitals-tell-doctors-they-llbe-fired-if-they-talk-to-press. Accessed December 31, 2020.

CBSNews. (2020). Drones used in effort to slow the spread of COID-19. April 27. https://www.cbsnews.com/news/coronavirus-drones-slow-spread-covid-19/. Accessed December 30, 2020.

Chamas, Z. (2020). Melbourne's COVID-19 restrictions are easing, but hundreds of refugees still face indefinite lockdown. ABC News, November 14. https://www.abc.net.au/news/2020-11-15/melbournes-detention-refugees-lockdowncoronavirus/12846434. Accessed December 29, 2020.

Christian, M.D., Sprung, C.L., King, M.A.m Richter, J.D., Kissoon, N., Devereaux, A.V. ..., $\&$ Task Force for Mass Critical Care. (2014). Triage: Taking care of the critically ill and injured during pandemics and disasters: CHEST consensus statement. Chest, 146(4Suppl.), e61S-74S.

Cohen, J., \& van der Meulen Rodgers, Y. (2020). Contributing factors to personal protective equipment shortages during the COVID-19 pandemic. Preventive Medicine, 141. doi:10.1016/j.ypmed.2020.106263.

Cohn, S.K., Jr. (2002). The Black Death: End of a paradigm. American Historical Review, 107(3), 703-738.

Committee on Economic, Social and Cultural Rights. (2000). General Comment No. 14: The right to the highest attainable standard of health (Art. 12). Doc. E/C.12/2000/4, August 11.

Convention on the Elimination of All Forms of Discrimination Against Women. 1249 U.N.T.S. 13, December 18, 1979. Entered into force September 3, 1991.

Convention on the Rights of the Child. 1577 U.N.T.S. 3, November 20, 1989. Entered into force September 2, 1990.

Convention on the Rights of Persons with Disabilities. G.A. Res. 61/106, January 24, 2007.

Council of Europe. (1950). European Convention for the Protection of Human Rights and Fundamental Freedoms, as amended by Protocols Nos. 11, 14, November 4, 1950, ETS 5.

Daniels, N. (1994). Four unresolved rationing problems: A challenge. Hastings Center Report, 24(4), 27-29.

Desmond, C., Lieberman, E., Alban, A., \& Ekström, A-M. (2008). Relative response ranking country responses to HIV and AIDS. Health and Human Rights, 10(2), 105-119. 
European Centre for Disease Control and Prevention. (2020). COVID-19 situation update worldwide, December 30. https://www.ecdc.europa.eu/en/geographical-distribution2019-ncov-cases. Accessed January 2, 2021.

European Commission. (2020). Overview of the impact of coronavirus measures on the marginalized Roma communities in the EU. https://ec.europa.eu/info/sites/info/ files/overview_of_covid19_and_roma_-_impact_-_measures__priorities_for_funding_-_23_04_2020.docx.pdf. Accessed December 9, 2020.

European Social Charter. (1961). E.T.S. 35, October 18. Entered into force February 26, 1965.

European Union Agency for Fundamental Rights. (2020). Coronavirus pandemic in the EUImpact on Roma and Travelers, Bulletin \#5, March 1-June 30. https://fra.europa.eu/en/publication/2020/covid19-rights-impact-september-1.

Accessed December 30, 2020.

Finkenstadt, D.J., Handfield, R., \& Guinto, P. (2020). Why the U.S. still has a shortage of medical supplies. Harvard Business Review, September 17. https://hbr.org/2020/09/why-the-u-s-still-has-a-severe-shortage-of-medical-supplies. Accessed December 31, 2020.

French, P.E. (2011). Enhancing the legitimacy of local government pandemic influenza planning through transparency and public engagement. Public Administration Review, 71(2), 253-264.

Galishoff, S. (1969). Newark and the great influenza pandemic of 1918. Bulletin of the History of Medicine, 43(3), 246-258.

Glenza, J. (2020). PPE shortage could last years without strategic plan, experts warn. The Guardian, August 17. https://khn.org/news/ppe-shortage-could-last-years-withoutstrategic-plan-experts-warn/. Accessed December 31, 2020.

Gordon, S. (2020). Why are blacks other minorities hardest hit by COVID-19? U.S. News \& World Report, May 6. https://www.usnews.com/news/health-news/articles/2020-0506/why-are-blacks-other-minorities-hardest-hit-by-covid-19. Accessed December 31, 2020.

Government of Kenya. (2020). Legal Notice No. 36. The Public Order (State Curfew) Order. http://kenyalaw.org/kl/fileadmin/pdfdownloads/LegalNotices/2020/LN36_2020.pdf. Accessed December 30, 2020.

Halpern, S. (2020). Can we track COVID-19 and protect privacy at the same time? New Yorker, April 27. https://www.newyorker.com/tech/annals-of-technology/can-wetrack-covid-19-and-protect-privacy-at-the-same-time. Accessed December 30, 2020.

Henderson, D.A., Courtney, B., Inglesby, T.V., Toner, E., \& Nuzzo, J.B. (2009). Public health and medical responses to the 1957-58 influenza pandemic. Biosecurity and Bioeterrorism: Biodefense Strategy, Practice, and Science, 7(3), 265-273.

Holmes, A. (2020). Housing the homeless population during the COVID-19 pandemic: Governments' ethical responsibility. CHLB Scholarship, 81. https://digital.sandiego.edu/law_chlb_research_scholarship/81. Accessed December 31, 2020.

International Convention on the Elimination of Racial Discrimination, 660 U.N.T.S. 195, G.A. Res. 2106 (XX), December 21, 1965, entered into force March 12, 1969.

International Covenant on Civil and Political Rights, 999 U.N.T.S. 171, G.A. Res. 2200A(XXI), December 16, 1966, entered into force March 23, 1976.

International Covenant on Economic, Social and Cultural Rights, 993 U.N.T.S. 3, G.A. Res. 2200A(XXI), December 16, 1966, entered into force January 3, 1976. 
Ireland Department of Health. (2020). Ethical framework for decisionmaking in a pandemic, September 24. https://www.gov.ie/en/publication/dbf3fb-ethical-framework-fordecision-making-in-a-pandemic/. Accessed December 31, 2020.

Jauhar, S. (2020). In a pandemic, do doctors still have a duty to treat? New York Times, April 2.

Kharpal, A. (2020). Use of surveillance to fight coronavirus raises concerns about government power after pandemic ends. CNBC, March 26. https://www.cnbc.com/2020/03/27/ coronavirus-surveillance-used-by-governmentsto-fight-pandemic-privacy-concerns.html. Accessed December 30, 2020.

Landman, K., \& Okereke, C. (2020). Commuting in a pandemic: These health workers are trekking and canoeing. National Public Radio, April 4. https://www.npr.org/ sections/goatsandsoda/2020/04/29/841830595/commuting-in-a-pandemic-these-

healthworkers-are-trekking-and-canoeing. Accessed December 30, 2020.

Langer, W.L. (1964). The Black Death. Scientific American, 212(2), 114-121.

Lebret, A. (2020). COVID-19 pandemic and derogation to human rights. Journal of Law and the Biosciences, May, 1-5. doi: 10.1093/jlb/lsaa015.

Malm, H., May, T., Francis, L.P., Omer, S.B., Salmon, D.A., \& Hood, R. (2008). Ethics, pandemics, and the duty to treat. American Journal of Bioethics, 8(8), 4-19.

Manelli, C. (2020). Whose life to save? Scarce resources allocation in the COVID-19 outbreak. Journal of Medical Ethics, 46, 364-366.

Melnychuk, R.M., \& Kenny, N.P. (2006). Pandemic triage: The ethical challenge. Canadian Medical Association Journal, 175(11), 1393-1394.

Morse, S.S., Mazet, J.A.K., Woolhouse, M., Parrish, C.R., Carroll, D., Haresh, W.B., Zambrana-Torrelio, C., ... \& Daszak, P. (2012). Prediction and prevention of the next pandemic zoonosis. Lancet, 380(9857), 1956-1965.

New York State Task Force on Life and the Law, New York State Department of Health. (2015). Ventilator allocation guidelines. https://nysba.org/app/uploads/2020/05/2015ventilator_guidelines-NYS-Task-Force-Life-and-Law.pdf. Accessed December 30, 2020.

Gad, E. (2020). Is the government using its own ethical framework? Blog post, Nuffield Council on Bioethics, April 24. https://www.nuffieldbioethics.org/blog/is-thegovernment-using-its-own-ethical-framework. Accessed December 31, 2020.

Olivarius, K. (2020). The dangerous burden of immunoprivilege. New York Times, April 12.

Ontario Human Rights Commission. (2020). Policy statement on human rights-based approach to managing the COVID-19 pandemic. http://www.ohrc.on.ca/en/policystatement-human-rights-based-approach-managing-covid-19-pandemic. Accessed December 30, 2020.

Organisation for Economic Co-operation and Development. (2019). Flattening the COVID19 peak: Containment and mitigation policies, March 24, 2020. https://www.oecd.org/coronavirus/policy-responses/flattening-the-covid-19-peakcontainment-and-mitigation-policies-e96a4226/. Accessed December 28, 2020.

Paluzzi, J., \& Farmer, P.. (2004). A tale of two viruses: Social responses to AIDS and SARS. The Brown Journal of World Affairs, 10(2), 199-206.

Patterson, K.D., \& Pyle, G.F (1991). The geography and mortality of the 1918 influenza pandemic. Bulletin of the History of Medicine, 65(1), 4-21.

Persad, G., Wertheimer, A., \& Emanuel, E.J. (2009). Principles for allocation of scarce medical intervention. Lancet, 373(9661), 423-431.

Pollitzer, R. (1959). Cholera. Geneva: World Health Organization. https://apps.who.int/iris/bitstream/handle/10665/41711/WHO_MONO_43?sequence= 1. Accessed December 28, 2020. 
Scheiber, N., \& Rosenthal, B.M. (2020). Nurses and doctors speaking out on safety now risk their job. New York Times, April 27.

Shanks, G.D., MacKenzie, A., Waller, M., \& Brundage, J.F. (2011). Low but highly variable mortality among nurses and physicians during the influenza pandemic of 1918-19. Influenza \& Other Respiratory Viruses, 5(3), 213-219.

Singer, P., Benatar, S.R., Bernstein, M., Daar, A.S., Dickens, B.M., MacRae, S.K., ..., \& Shaul, R.Z. (2003). Ethics and SARS: Lessons from Toronto. British Medical Journal, 327(7427), 1342-1344.

Slack, P. (1988). Responses to plague in early modern Europe: The implications of public health. Social Research, 55(3), 433-453.

Smith, M., \& Upshur, R. (2019). Pandemic disease, public health, and ethics. In A.C. Mastroianni, J.P. Kahn, N.E. Kass (Eds.), The Oxford handbook of public health ethics (pp. 797-810). New York: Oxford University Press.

Thomas, E., \& Gittleson, B. (2020). Trump's own words contradict claim he always viewed virus as 'very serious.' ABC News, March 19. https://abcnews.go.com/Politics/trumps-words-contradict-claim-viewedcoronavirus/story?id=69662788. Accessed December 29, 2020.

Tognotti, E. (2013). Lessons from the history of quarantine, from plague to influenza. Emerging Infectious Diseases, 19(2), 254-259.

UNAIDS. (2020). Rights in a pandemic. https://www.unaids.org/en/resources/documents/ 2020/rights-in-a-pandemic. Accessed December 30, 2020.

United Nations Department of Global Communications. (2020). UN supporting 'trapped' domestic violence victims during COVID-19 pandemic. https://www.un.org/en/ coronavirus/un-supporting-\%E2\%80\%98trapped\%E2\%80\%99-domestic-violencevictims-during-covid-19-pandemic. Accessed December 9, 2020.

United Nations Women. (n.d.). The shadow epidemic: Violence against women during COVID-19. (https://www.unwomen.org/en/news/in-focus/in-focus-gender-equalityin-covid-19-response/violence-against-women-during-covid-19). Accessed December 9, 2020.

Universal Declaration of Human Rights, G.A. Res. 217A(111), December 10, 1948.

University of Toronto Joint Centre for Bioethics Pandemic Influenza Working Group. (2005). Stand on guard for thee. A report of the University of Toronto Joint Centre for Bioethics Pandemic Influenza Working Group. http://jcb.utoronto.ca/people/documents/ upshur_stand_guard.pdf. Accessed December 30, 2020.

van Dorn, A., Cooney, R.E., \& Sabin, M.L. (2020). COVID-19 exacerbating inequalities in the US. Lancet, 395, 1243-1244.

Walker, N.F., \& Whitty, C.J.M. (2015). Tackling emerging infections: clinical and public health lessons from the West African Ebola virus disease outbreak, 2014-2015. Clinical Medicine (London), 15(5), 457-460. [Erratum in "Tackling emerging infections: clinical and public health lessons from the West African Ebola virus disease outbreak, 2014-2015." Clinical Medicine (London), 2015].

Wilder, J.M. (2020). The disproportionate impact of COVID-19 on racial and ethnic minorities in the United States. Clinical Infectious Diseases, ciaa 959. doi:10.1093/cid/ciaa959.

World Health Organization. (2020, May 6). Key criteria for the ethical acceptability of COVID-19 human challenge studies. https://www.who.int/ethics/publications/keycriteria-ethical-acceptability-of-covid-19-human-challenge/en/. Accessed December 30, 2020. 
World Health Organization. (2020). Shortage of personal protective equipment endangering health workers worldwide. March 3. https://www.who.int/news/item/03-03-2020shortage-of-personal-protective-equipment-endangering-health-workers-worldwide. Accessed December 31, 2020.

World Health Organization Regional Office for the Eastern Mediterranean. (2020). Levels of domestic violence increase globally, including in the Region, as COVID-19 pandemic escalates. $\quad$ http://www.emro.who.int/violence-injuries-disabilities/violencenews/levels-of-domestic-violence-increase-as-covid-19-pandemic-escalates.html. Accessed December 9, 2020.

Zuger, A. \& Miles, S.H. (1987). Physicians, AIDS, and occupational risk. Historic traditions and ethical obligations. Journal of the American Medical Association, 258(14), 19241928. 